\title{
Influence of organic and mineral amendments on microbial soil properties and processes
}

\author{
C. Stark ${ }^{\mathrm{a}, \mathrm{b} *}$, L.M. Condron ${ }^{\mathrm{b}}$, A. Stewart ${ }^{\mathrm{c}}$, H.J. Di ${ }^{\mathrm{b}}$, M. O'Callaghan ${ }^{\mathrm{d}}$
}

${ }^{a}$ Teagasc, Johnstown Castle, Wexford, Ireland

${ }^{\mathrm{b}}$ Agriculture \& Life Sciences Division, PO Box 84, Lincoln University, Canterbury, New Zealand

${ }^{\mathrm{c}}$ National Centre for Advanced Bio-protection Technologies, PO Box 84, Lincoln University, Canterbury, New Zealand

${ }^{\mathrm{d}}$ AgResearch, PO Box 60, Lincoln, Canterbury, New Zealand

* Corresponding author. Tel.: +353 53 71243; fax: +353 5342213

Correspondence address: Teagasc, Johnstown Castle, Wexford, Ireland; email: christine.stark@teagasc.ie

\begin{abstract}
Microbial diversity in soils is considered important for maintaining sustainability of agricultural production systems. However, the links between microbial diversity and ecosystem processes are not well understood. This study was designed to gain better understanding of the effect of short-term management practices on the microbial community and how changes in the microbial community affect key soil processes. The effects of different forms of nitrogen $(\mathrm{N})$ on soil biology and $\mathrm{N}$ dynamics was determined in two soils with organic and conventional management histories that varied in soil microbial properties but had the same fertility. The soils were amended with equal amounts of $\mathrm{N}\left(100 \mathrm{~kg} \mathrm{ha}^{-1}\right)$ in organic (lupin (Lupinus angustifolius L.)) and mineral form (urea), respectively. Over a 91-day period, microbial biomass $\mathrm{C}$ and $\mathrm{N}$, dehydrogenase enzyme activity, community structure of actinomycetes and $\alpha$ proteobacteria (by denaturing gradient gel electrophoresis (DGGE) following PCR amplification of 16S rDNA fragments) and $\mathrm{N}$ mineralisation were measured. Lupin amendment resulted in a 2 to 5 -fold increase in microbial biomass and enzyme activity, while these parameters did not differ significantly between the urea and control treatments. The PCR-DGGE analysis showed that the addition of mineral and organic compounds had an influence on the microbial community composition in the short-term (up to 10 days) but the effects were not sustained over the 91-day incubation period. Microbial community structure was strongly influenced by the presence or lack of substrate, while the type of amendment (organic or mineral) had an effect on microbial biomass size and activity. These findings show that the addition of green manures improved soil biology by increasing microbial biomass and activity irrespective of management history, that no direct relationship existed among microbial structure, enzyme activity and $\mathrm{N}$ mineralisation, and that microbial community structure (by PCR-DGGE) was more strongly influenced by inherent soil and environmental factors than by short-term management practices.
\end{abstract}

Keywords: Microbial community structure; DGGE; Nitrogen mineralisation; Organic and conventional farming practices; Lupin (Lupinus angustifolius L.) green manure; urea.

\section{Introduction}

Farming practices commonly associated with organic farming have a positive effect on the soil microbial diversity and, consequently, soil processes (Girvan et al., 2003; Hole et al., 2005). In comparison, there is little evidence in the literature of direct negative effects of mineral fertiliser and pesticide use on the soil microbial community in arable farming (e.g. Fraser et al., 1988; Fauci and Dick, 1994). It is noted that such practices may have different impacts on other parts of the 
farm system (Kirchmann and Thorvaldsson, 2000; Stolze et al., 2000). As observed by Bossio et al. (1998), this strongly suggests that the soil microbial community does not benefit from a particular management system (such as organic or conventional), but from specific farming techniques (e.g. green manuring, use of catch crops, crop rotations, crop residue management). Leguminous plants are often part of crop rotations, either as components of the pasture phase (e.g. clover) or as green manure crops (e.g. lupin), which add labile organic matter to the soil after incorporation. Legumes are an important source of $\mathrm{N}$ for most organic systems, especially in New Zealand, where crops under organic management rely almost exclusively on $\mathrm{N}$ released from soil organic matter via mineralisation. This highlights the importance of green manure crops and the dependence on biological processes to supply sufficient amounts of $\mathrm{N}$ to crops in organic farming systems. However, including green manures in crop rotations is considered good management practice in any agricultural production system because of their many positive effects on soil fertility and quality (Doran et al., 1988; Shepherd et al., 2000; Watson et al., 2002). As these practices are commonly linked to organic farming systems, soils cultivated under contrasting management regimes should show differences in biological soil properties and application of certain farming practices, such as green manure amendment, should be reflected in the composition of the microbial community and in related soil processes (Gunapala and Scow, 1998; Lundquist et al., 1999).

Interpretation of experiments examining in situ responses of soil microorganisms should be made with caution as incubation studies represent model systems under optimum conditions that rarely occur in the field. However, assessing soil properties under constant conditions allows variables such as soil moisture levels, temperature, microbial-plant interactions and soil type, to be studied individually. An incubation experiment was conducted to study interactions of soil microbial properties and soil processes by determining the effects of farm management history and short-term management practices on the microbial community and how changes in the microbial community affect $\mathrm{N}$ mineralisation. Soils with different farming histories were amended with the same amounts but different forms of $\mathrm{N}$ substrate (mineral as urea, organic as lupin) to study the effects on the microbial community and on key soil processes. The objectives of this study were to determine what links exist between microbial community composition and soil processes and how microbial biomass size and activity, gross $\mathrm{N}$ mineralisation and the community structure of selected microbial groups were influenced (a) by farm management history as opposed to short-term management practices, and (b) by the addition of different forms of $\mathrm{N}$.

\section{Materials and methods}

\subsection{Site description and experimental design}

Top soil samples $(0-15 \mathrm{~cm})$ were collected from two sites under the same environmental conditions (approximately $2 \mathrm{~km}$ apart) within the cropping farm at Lincoln University, Canterbury,

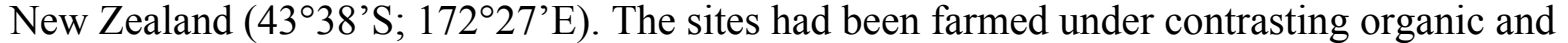
conventional management systems for a substantial period of time. The organic site (ORG) was established in 1976, while the conventional site (CON) had been maintained under intensive mixed cropping for over 100 years. The soil at both sites was a Wakanui silt loam (free draining to $75 \mathrm{~cm}$ ) (Mottled Immature Pallic Soil, NZ classification; Udic Ustochrept, USDA) with broadly comparable chemical and physical soil properties (Table 1).

The samples were air dried and sieved $(2 \mathrm{~mm})$ and, of each soil, $1.5 \mathrm{~kg}$ dry weight equivalent were placed in each of nine $2 \mathrm{~L}$ plastic containers with aeration provided by two $5 \mathrm{~mm}$ diameter holes in the lid. Initially and throughout the course of the experiment (every 4 days), soil moisture was adjusted to $70 \%$ water holding capacity based on weight loss by adding deionised water as a fine spray. The soils were incubated in the laboratory at a constant temperature of $20^{\circ} \mathrm{C}$. Three treatments were applied to both soils after 3 weeks of pre-incubation. Nitrogen (equivalent to $\left.100 \mathrm{~kg} \mathrm{ha}^{-1}\right)$ was added to the soils in mineral form as urea $(46 \% \mathrm{~N}, 20 \% \mathrm{C})$ and organic form as ground $(2 \mathrm{~mm})$ lupin $(2.3 \% \mathrm{~N}, 44 \% \mathrm{C})$. The amounts added were equivalent to an application rate 
of $217 \mathrm{~kg} \mathrm{ha}^{-1}$ for urea and $4.3 \mathrm{tha}^{-1}$ for lupin (assuming a bulk density of $1.4 \mathrm{~g} \mathrm{~cm}^{-3}$ and a depth of $7.5 \mathrm{~cm}$ ). The control treatment did not receive any amendments. Each treatment had three replicates.

The soils were sampled $0,3,6,10,14,35$ and 91 days after amendment by removing approximately $200 \mathrm{~g}$ of moist soil from the entire depth of each container. After each sampling, the soils in the containers were re-compacted to an approximate bulk density of $1 \mathrm{~g} \mathrm{~cm}^{-3}$.

\subsection{Soil analyses}

On all sampling dates, samples were analysed for total mineral $\mathrm{N}\left(=\mathrm{NO}_{3}{ }^{-}-\mathrm{N}+\mathrm{NH}_{4}{ }^{+}-\mathrm{N}+\right.$ $\left.\mathrm{NO}_{2}^{-}-\mathrm{N}\right)$ (Blakemore et al., 1987), microbial biomass $\mathrm{C}\left(\mathrm{C}_{\text {mic }}\right)$ and $\mathrm{N}\left(\mathrm{N}_{\text {mic }}\right)$ (Sparling and West, 1988) and dehydrogenase activity (DHH) (Thalmann, 1968). Analyses were carried out on field moist samples. Total $\mathrm{C}$ and $\mathrm{N}\left(\mathrm{C}_{\text {tot }}\right.$ and $\left.\mathrm{N}_{\text {tot }}\right)$ were determined in air-dried samples on a Leco® $\mathrm{CNS}$ 2000 elemental analyser.

On four occasions (days $0,10,35$ and 91) gross $\mathrm{N}$ mineralisation rate (MIN rate) was estimated using the ${ }^{15} \mathrm{~N}$ dilution technique (Barraclough, 1995; Zaman et al., 1999). In brief, four $20 \mathrm{~g}$ subsamples of each soil were weighed into vented plastic containers. Two samples (t1 and t2) were amended with $1 \mathrm{ml}{ }^{15} \mathrm{~N}$-labelled $\mathrm{NH}_{4} \mathrm{SO}_{4}$ solution (ammonium sulphate; $99 \%$ enrichment) $\left(=2 \mu \mathrm{g} \mathrm{NH}_{4}{ }^{+}-\mathrm{N} \mathrm{g}^{-1}\right.$ soil) each and incubated at $20^{\circ} \mathrm{C}$ for $24 \mathrm{~h}(\mathrm{t} 1)$ and $5 \mathrm{~d}(\mathrm{t} 2)$, respectively. After the incubation period, the samples were extracted with $2 \mathrm{M} \mathrm{KCl}$ and analysed for $\mathrm{NH}_{4}{ }^{+}-\mathrm{N}$ content using a Flow Injection Analyser (Tecator, Sweden). The ${ }^{15} \mathrm{~N}$ content in the $\mathrm{NH}_{4}{ }^{+}-\mathrm{N}$ pool was recovered by the diffusion method described by Stark and Hart (1996) and determined by isotope ratio mass spectrometry (Europa Scientific, UK). The gross mineralisation rate was calculated from the rate at which the relative abundance of ${ }^{15} \mathrm{~N}$ and the size of the $\mathrm{NH}_{4}{ }^{+}$-pool changed over time (Barraclough, 1995; Di et al., 2000).

\subsection{Community composition of selected groups of microorganisms}

A PCR-DGGE approach (denaturing gradient gel electrophoresis following amplification of 16S rDNA fragments by polymerase chain reaction) was used to determine the composition of the microbial community in the soils on three occasions (days 0,10 and 91 after incorporation). Community DNA was extracted from the soil samples using the UltraClean ${ }^{\mathrm{TM}}$ Soil DNA kit (MoBio Laboratories, Inc., USA) according to manufacturer's instructions and 16S rDNA of actinomycetes,$\alpha$ proteobacteria and pseudomonads (sensu stricto) was amplified using a nested PCR approach. In the first round, forward primer F243 (GGA TGA GCC CGC GGC CTA) (Heuer et al., 1997) was used for actinomycetes and F203 $\alpha$ (CCG CAT ACGCCC TAC GGG GGA AAG ATT TAT) for $\alpha$ proteobacteria (Gomes et al., 2001), both with R1494 (CTA CGG YTA CCT TGT TAC GAC) (Weisburg et al., 1991) as reverse primer. For pseudomonads, the primers ps for (GGT CTG AGA GGA TGA TCA GT) and ps rev (TTA GCT CCA CCT CGC GGC) (Widmer et al., 1998; Clegg et al., 2003) were used. The second amplification, was carried out with F984GC (AAC GCG AAG AAC CTT ACC GCC CGG GGC GCG CCC CGG GCG GGG CGG GGG CAC GGG

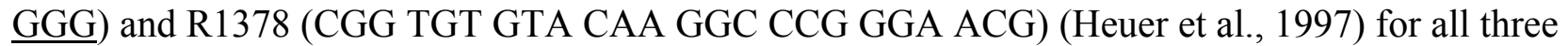
groups. A GC-rich sequence was attached to the forward primer F984 to prevent complete melting during DGGE separation (underlined) (Muyzer et al., 1993). For all amplifications, $25 \mu 1$ reaction mixtures were used containing $2.5 \mu 1$ HotMaster Taq buffer (10x) (Eppendorf, Germany), $2 \mu 1$ dNTPs $(2.5 \mathrm{mM}), 1 \mu 1$ bovine serum albumin $\left(0.01 \mathrm{~g} \mathrm{ml}^{-1}\right)$ ( $1^{\text {st }}$ round only), $1 \mu 1$ each of forward and reverse primers $(10 \mu \mathrm{M}), 0.25 \mu 1$ HotMaster Taq DNA polymerase (Eppendorf, Germany) ( 1.25 units) and $1 \mu \mathrm{l}$ of template DNA ( $1{ }^{\text {st }}$ round) or diluted PCR product from the first round ( 1 in 200) $\left(2^{\text {nd }}\right.$ round $)$. Thermal cycling conditions for the respective primer pairs were as follows: 5 min at $94^{\circ} \mathrm{C} ; 35$ cycles of $30 \mathrm{~s}$ at $95^{\circ} \mathrm{C}, 30 \mathrm{~s}$ at $63^{\circ} \mathrm{C}$ and $1 \mathrm{~min}$ at $68^{\circ} \mathrm{C} ; 5 \mathrm{~min}$ at $68^{\circ} \mathrm{C}(\mathrm{F} 243-\mathrm{R} 1494) ; 5$ min at $94^{\circ} \mathrm{C} ; 35$ cycles of $30 \mathrm{~s}$ at $95^{\circ} \mathrm{C}, 30 \mathrm{~s}$ at $56^{\circ} \mathrm{C}$ and $1 \mathrm{~min}$ at $68^{\circ} \mathrm{C} ; 5 \mathrm{~min}$ at $68^{\circ} \mathrm{C}(\mathrm{F} 203 \alpha-$ R1494); $5 \mathrm{~min}$ at $95^{\circ} \mathrm{C} ; 35$ cycles of $1 \mathrm{~min}$ at $95^{\circ} \mathrm{C}, 1 \mathrm{~min}$ at $62^{\circ} \mathrm{C}$ and $2 \mathrm{~min}$ at $72^{\circ} \mathrm{C} ; 10 \mathrm{~min}$ at 
$72^{\circ} \mathrm{C}$ (ps for-ps rev); $5 \mathrm{~min}$ at $94^{\circ} \mathrm{C} ; 35$ cycles of $1 \mathrm{~min}$ at $94^{\circ} \mathrm{C}, 1 \mathrm{~min}$ at $53^{\circ} \mathrm{C}$ and $2 \mathrm{~min}$ at $72^{\circ} \mathrm{C}$; $10 \mathrm{~min}$ at $72^{\circ} \mathrm{C}$ (F984GC-R1378). Amplified DNA was verified by electrophoresis of aliquots of PCR mixtures $(5 \mu \mathrm{l})$ in 1\% agarose in $1 \times$ TAE buffer $(0.04 \mathrm{M}$ Tris-acetate, $1 \mathrm{mM}$ EDTA; $\mathrm{pH} 8.5)$.

The DCode Universal Mutation Detection System (Bio-Rad, Hercules, CA) was used for the DGGE (Denaturing Gradient Gel Electrophoresis). Six microliters of PCR product plus $4 \mu 1$ of water were loaded onto an $8 \%(\mathrm{w} / \mathrm{v})$ acrylamide gel (acrylamide/bis solution, 37.5:1) with a linear chemical gradient ( $7 \mathrm{M}$ urea and $40 \%$ (v/v) formamide) of $40-55 \%$. The gels were run in $1 \times \mathrm{TAE}$ buffer (preheated to $60^{\circ} \mathrm{C}$ ) for $10 \mathrm{~min}$ at $200 \mathrm{~V}$ followed by $16 \mathrm{~h}$ at $80 \mathrm{~V}$. The gels were silver stained to detect DNA using a standard protocol (Sanguinetty et al., 1994). Gels were dried overnight at $60^{\circ} \mathrm{C}$ before being scanned using a GS-700 Imaging Densitometer (Bio-Rad, USA).

\subsection{Statistical analysis}

All data was normally distributed and untransformed data was analysed by repeated measures analysis of variance, general linear model analysis of variance or correlation analysis where appropriate using GenStat Release 7.1 (C2003, Lawes Agricultural Trust, Rothamsted Experimental Station, UK) or Minitab ${ }^{\circledR}$ for Windows Release 14.1 (C2003, Minitab Inc., USA). A $95 \%$ confidence limit $(\mathrm{p}<0.05)$ was chosen to indicate differences between samples and least significant differences (LSD) were calculated when samples were significantly different. DGGE patterns were analysed by cluster analysis according to Ward (1963) using Quantity One 1-D Analysis Software (Version 4.5.2) (Bio-Rad, USA).

\section{Results}

\subsection{Soil properties and processes}

Repeated measures analysis of variance revealed which of the factors time (six sampling points), treatment (addition of lupin, urea or control) and management history (ORG or CON) had the greatest effect on the soil properties measured (Figure 1, Table 2). Temporal variation was based on the significant increase or decrease (for microbial $\mathrm{C}: \mathrm{N}$ ) in soil property levels directly after amendment with both soils showing similar trends (see Figures 1and 2). Hence, significant differences between sampling points could be observed for most of the parameters (except total C). However, temporal variation could account only for a small percentage of the total variation (e.g. $\mathrm{R}^{2}$ $=14.6 \%$ for $\mathrm{C}_{\text {mic }}$ and 5.33 for $\mathrm{N}_{\min }$ ) and $\mathrm{F}$ values were mostly small (Table 2 ). After the initial rise, the curves showed little change with time. Both soil origin (farm) and treatment had significant effects on most parameters (except microbial $\mathrm{C}: \mathrm{N}, \mathrm{N}$ mineralisation and $\mathrm{C}_{\mathrm{mic}}$ ). Total $\mathrm{C}$ and $\mathrm{N}$ were more strongly affected by soil origin (farm) than treatment, while microbial biomass $\mathrm{C}$ and $\mathrm{N}$, $\mathrm{DHH}$, microbial quotient $\left(\mathrm{C}_{\mathrm{mic}}: \mathrm{C}_{\text {tot }}\right.$ ratio), $\mathrm{C}: \mathrm{N}$ ratio and mineral $\mathrm{N}$ were mainly affected by the different amendments.

The addition of lupin resulted in a significantly larger microbial biomass and activity, while total mineral $\mathrm{N}$ was higher in the urea treatment (Table 3 ). Immediately after the amendment with lupin (day 3), $\mathrm{C}_{\text {mic }}$ and $\mathrm{N}_{\text {mic }}$ concentrations were twice and DHH rates approximately 5 times that of the control and urea treatments and remained elevated until the end of the experiment (Figure 1, Table 3). In contrast, the urea treatment did not significantly affect the soil properties measured when compared to the control, except for total mineral $\mathrm{N}$, which increased considerably after addition of urea, and microbial $\mathrm{C}: \mathrm{N}$ ratio, which was similar for lupin treatment and control but significantly lower in the urea amended soils. These effects were the same for both soils. Significant differences in total $\mathrm{C}$ and $\mathrm{N}(\mathrm{CON}>\mathrm{ORG}), \mathrm{DHH}$ rates $(\mathrm{ORG}>\mathrm{CON})$, microbial quotient $(\mathrm{ORG}>\mathrm{CON})$ and $\mathrm{N}_{\min }(\mathrm{CON}>\mathrm{ORG})$ could be observed in the soils from the two sites, while microbial biomass $\mathrm{C}$ and $\mathrm{N}$ were not affected by soil origin (Table 3 ).

Between day 0 and day $3, \mathrm{C}_{\text {mic }}, \mathrm{N}_{\text {mic }}$, mineral $\mathrm{N}$ levels and the microbial quotient in $\mathrm{ORG}$ underwent greater increases than in $\mathrm{CON}$ samples as a result of the amendments. For example, 
microbial C levels increased by a factor of 2.23 in ORG compared to 1.95 in CON samples, and mineral $\mathrm{N}$ levels increased twofold in ORG samples after urea amendment compared to an increase by a factor of 1.8 in the soils from CON. DHH activity, on the other hand, was more strongly affected in soils from $\mathrm{CON}$ by the addition of lupin and urea, respectively (Lupin: increase by factor 4.6 and 5.6 in ORG and CON samples, respectively; urea: 1.39 [ORG] vs. 1.55 [CON]). After 91 days of incubation, levels of microbial $\mathrm{N}$ and $\mathrm{DHH}$ activity rates were relatively higher in soils from $\mathrm{CON}$ (average change from day 0 for $\mathrm{N}_{\text {mic }}$ : 1.0 and 1.2 for $\mathrm{ORG}$ and $\mathrm{CON}$, respectively; DHH: 1.38 [ORG] vs. 1.82 [CON]), while $\mathrm{N}_{\min }$ and the microbial quotient remained higher in ORG. Total mineral $\mathrm{N}$ levels in the soil from CON were approximately twice (urea) and 1.4 times (lupin) as high at the last sampling compared to day 0, whereas in ORG samples levels increased 2.5-fold for urea and 1.6-fold for lupin between the first and last sampling. Microbial biomass $\mathrm{C}$ had changed at similar rates for samples from ORG and CON. This shows that the various soil properties were affected differently by the treatments in the two soils and did not change at the same proportions.

These relative observations are supported by the results of the repeated measures analysis. Most of the soil properties were strongly affected by the interactions of the three factors and of all interactions, treatment*time and farm*time interactions had the biggest influence. As with the single effects, the changes in microbial biomass $\left(<0.001\right.$ for $\mathrm{C}_{\text {mic }}$ and 0.01 for $\left.\mathrm{N}_{\text {mic }}\right)$, activity $(<0.001)$ and microbial quotient $(<0.001)$ and total mineral $\mathrm{N}(0.04)$ were mainly driven by treatment, whereas farm had a stronger effect on total $\mathrm{N}(0.05)$ and microbial $\mathrm{C}: \mathrm{N}$ ratio $(0.02)$ (effects on $\mathrm{C}_{\text {tot }}$ and $\mathrm{C}: \mathrm{N}$ ratio were not significant) (Table 2). The microbial C:N ratio was strongly affected by time*treatment interactions and was significantly lower in the urea amended soil shortly after application, however, no significant differences were observed at the last sampling (Figure 1) and overall differences among treatments were small (Table 3). Farm*treatment interaction only had a significant effect on DHH $(<0.001)$ and microbial biomass $\mathrm{N}(0.02)$. However, the data suggest that the interactions of treatment and soil origin with time were not affecting the parameters to a large extent ( $\mathrm{R}^{2}$ and $\mathrm{F}$ values are generally smaller than those of single effects).

\subsection{Community composition of bacteria and actinomycetes}

Initially, replicate DNA extracts from ORG and CON soils, respectively, using the three primer sets revealed very consistent DGGE profiles for $\alpha$ proteobacteria and actinomycetes, while pseudomonads seemed to be more variable with differences between replicate banding patterns as great as between the soils (day 0 sampling, i.e. DNA extracted before amendment with lupin and urea, respectively). DGGE profiles of $\alpha$ proteobacteria and actinomycetes revealed distinct differences between the two soils. For the three primer sets, number of bands was similar for both sites.

At the 10 day sampling, DGGE profiles of $\alpha$ proteobacteria and actinomycete communities showed clear differences among the three treatments (lupin, urea, control) and between the two soils (ORG and CON). Figure 3 shows actinomycete banding patterns as an example. Cluster analyses supported these observations: the samples from different treatments could be distinguished from each other and treatment replicates were sorted into the same clusters (Figure 4). In both soils, the control was most different from the other two treatments and lupin and urea clusters were more alike.

For pseudomonads, reproducibility of DGGE profiles was not as good as for the other two primer sets, i.e. variability between replicates was larger. It was, however, possible to detect differences between treatments and soils. Samples from the control treatment were most similar to each other and could be visually distinguished from urea and lupin treatments in both soils, which was confirmed by cluster analysis (Figure 4). For pseudomonads, the differences in DGGE profiles between ORG and CON samples detected 10 days after the amendment persisted over the course of the incubation experiment and were still apparent after 91 days. In contrast, the banding patterns for $\alpha$ proteobacteria and actinomycetes did not show major differences between treatments after 91 
days (Figure 3). Variability among pseudomonad replicates was similarly high to that in the previous samplings and differences between the treatments were less distinct than in the day 10 sampling. Consequently, the samples of the different treatments could not be grouped into separate clusters and the degree of similarity within each cluster was lower than for previous analyses (Figure 5).

\subsection{Linkages among soil properties and processes}

The correlations among the soil properties were similar for ORG and CON samples. The soil biological soil properties $\left(\mathrm{C}_{\text {mic }}, \mathrm{N}_{\text {mic }}, \mathrm{DHH}\right)$ showed strong positive correlations to each other $\left(\mathrm{R}^{2}>0.88\right)$ and were negatively correlated to total mineral $\mathrm{N}$. Total $\mathrm{C}$ and $\mathrm{N}$ were positively correlated to each other $\left(\mathrm{R}^{2}=0.92\right)$ and to microbial biomass $\mathrm{C}$, while they did not show any correlations with dehydrogenase activity. Gross mineralisation rate correlated positively with the soil biological properties and negatively with mineral $\mathrm{N}$, and total $\mathrm{C}$ and $\mathrm{N}$.

Correlation analyses for each treatment separately (Table 4) revealed weaker correlations for urea and control than for the lupin-amended soils, i.e. the measured properties were not as closely linked to each other, while for the lupin treatment most soil properties correlated strongly with each other. Correlations between mineralisation rate and $\mathrm{N}_{\min }$ and total $\mathrm{C}$ and $\mathrm{N}$ were, however, stronger in the urea and control treatment, compared to the lupin-amended soil. Overall, the correlations for the three treatments followed the same trends as the overall correlations.

\section{Discussion}

\subsection{Effect of management history}

The influence of farm management history was most evident on total $\mathrm{C}$ and $\mathrm{N}$, which showed greater variation between soils than among treatments. However, absolute differences between ORG and CON were small and results were consistent with the expectation that total $\mathrm{C}$ and $\mathrm{N}$ change slowly under the influence of soil amendments and are usually unaffected by short-term management practices (Wander et al., 1994).

Overall means of DHH activity, mineral $\mathrm{N}$, microbial quotient and gross mineralisation rate were also significantly different in ORG and CON soils, and microbial biomass $\mathrm{C}$ and $\mathrm{N}$ were not significantly affected but higher in samples from ORG, while microbial $\mathrm{C}: \mathrm{N}$ ratio was higher in CON. Considering the initially lower levels of $\mathrm{C}_{\text {mic }}$ and gross $\mathrm{N}$ mineralisation rates in ORG samples, the increase in microbial biomass and activity following the amendments is more pronounced, which suggests a more responsive community in the soil from ORG (Vinten et al., 2002). The higher mineralisation rates and mineral $N$ levels in ORG samples also suggest a stronger response to the lupin and urea addition compared to CON. Overall, the differences and similarities between soils from ORG and CON persisted over the incubation period at similar levels. This indicates that incubation with or without amendment had the same effect on the two soils and that both soils had microbial communities that were adequate to respond to the addition of organic or mineral $\mathrm{N}$, respectively, which is supported by the interaction effects on the soil parameters. Differences caused by farm*treatment interaction were mostly statistically insignificant and for the other interactions the generally low F values indicated that the main effects time, treatment and soil origin are of greater importance in influencing the soil properties measured than the interactive effects. The variation observed for each interaction could explain only a small percentage of the total variation, which indicates that random effects influenced the parameters measured.

DGGE analysis following PCR amplification of 16S rDNA fragments of actinomycetes, $\alpha$ proteobacteria and pseudomonads revealed that soils from ORG and CON could clearly be distinguished based on bacterial and actinomycete community structure at the initial sampling. This indicates that distinctly different communities were present in ORG and CON soils; visual assessment suggested that obvious differences were sustained over the course of the experiment and 
that the microbial communities in each soil did not change much over time. The results suggest that the microbial communities assessed by PCR-DGGE were stable in both soils and unaffected by the incubation process. However, microbial diversity or species richness could have changed over time and the incubation could have affected other microbial groups, e.g. fungi. The higher initial microbial $\mathrm{C}: \mathrm{N}$ ratio in $\mathrm{CON}$ samples indicated that the biomass in this soil was dominated by fungi as microbial $\mathrm{C}: \mathrm{N}$ can be seen as a measure for fungal to total microbial biomass ratio in soils (Joergensen et al., 1995). However, at the end of the experiment, there was no overall significant difference between the soils and based on their microbial $\mathrm{C}: \mathrm{N}$ ratios both soils had a similarly composed microbial biomass. In conjunction with the DGGE results, this suggests that the fungal component had changed in size over the period of the incubation and that this effect was the same for both soils.

\subsection{Effect of short-term management practices}

This study, in agreement with other research, showed that the addition of lupin had a positive effect on community size and activity (Fraser et al., 1988; Robertson and Morgan, 1996; Fontaine et al., 2003) resulting in an increase in microbial biomass size and activity. Levels remained significantly higher than those of other treatments for the rest of the study. The addition of urea, on the other hand, did not significantly affect levels of microbial biomass $\mathrm{C}$ and $\mathrm{N}$, total $\mathrm{C}$ and $\mathrm{N}$ and microbial activity compared to the control soil. Only the microbial C:N ratio was significantly lower after urea amendment compared to lupin and control treatments. This suggests that over the 91 day incubation period amendment with urea did not have a major effect on soil microbial properties, while total mineral $\mathrm{N}$ approximately doubled following the addition of urea (resulting from the large increase in $\mathrm{NH}_{4}-\mathrm{N}$ ), and levels remained significantly higher compared to the lupin and control treatments.

The urea amendment initially resulted in an increase in DHH activity and a decrease in microbial biomass $\mathrm{C}$ and the microbial C: $\mathrm{N}$ ratio. Correspondingly, Omar and Ismail (1999) found that the addition of urea at two rates $\left(0.2\right.$ and $\left.0.5 \mathrm{mg} \mathrm{N} \mathrm{g}^{-1}\right)$ caused a rise in $\mathrm{pH}$ and decreased certain microbial populations (assessed by soil dilution plating), while increasing others and, therefore, changing species composition in the treated soils. Mahmood et al. (1997) also reported a decrease in microbial biomass after the addition of urea at $200 \mathrm{~kg} \mathrm{ha}^{-1}$ under wheat but not under maize. However, this rate is twice as high as that applied in this study and the presence of plants meant factors other than fertilisation influenced the microbial communities. The increase in microbial biomass $\mathrm{C}$ and the microbial $\mathrm{C}: \mathrm{N}$ ratio from day 14 in our study suggests that adding urea had a delayed positive effect on microbial growth. The decrease in microbial C:N ratio directly after amendment indicates an effect in particular on the fungal biomass in soils (Joergensen et al., 1995). This decline is strongest for the urea amended soils, indicating that urea has a negative influence on the fungal community. There is evidence that increases in $\mathrm{N}$ availability have a negative effect on fungal biomass and the fungal-bacterial biomass ratios. However, the literature suggests that this is primarily a long-term issue in grasslands, forest soils or under succession gradients, i.e. in uncultivated soils and where repeated fertiliser application allows for a significant and long lasting accumulation of nutrients (e.g. Lovell et al., 1995; Bardgett and McAlister, 1999; Ohtonen et al., 1999; Smith et al., 2003; Frey et al., 2004). The same would not be the case in cropping soils where high $\mathrm{N}$ fertilisation does not result in $\mathrm{N}$ accumulation in the same way as in grasslands and forests as most nutrients applied are exported during harvest. It is generally accepted that organic matter additions (crop residue, green manuring) have the largest influence on microbial numbers and activity, while mineral fertilisation has a limited effect on the microbial community in cropping situations (e.g. Fraser et al., 1988). Marschner et al. (2003), who investigated the effects of longterm organic and inorganic amendments on the soil microbial community, found that mineral fertilisation did not alter the microbial community composition and that treatments generally differed in bacterial but not eukaryotic community structure. Similarly, Fauci and Dick (1994) concluded that addition of inorganic $\mathrm{N}$ sources had no major effect on soil enzyme activities and 
microbial biomass in the short-term, while long-term additions decreased microbial biomass size and activity. In addition, cropping soils are typically dominated by bacteria and have low fungal biomass as soil cultivation destroys most of the hyphal structures. As the decrease in microbial C:N ratio can be observed for all treatments and the final microbial $\mathrm{C}: \mathrm{N}$ ratio is lower than that measured at day 0 , it is feasible that regular sampling and mixing of the soils would have limited the establishment of fungal communities. At the final sampling, all samples show similar microbial $\mathrm{C}: \mathrm{N}$ ratios indicating that the negative effects were only temporary (strongest decrease during period of high sampling frequency) and that the soils have comparable microbial community compositions at the end of the experiment.

Until day 10, DHH activity was similar for the urea and control treatments. After that, the enzyme activity declined in the urea treatment below rates measured for the control and levels remained significantly lower for the rest of the incubation period. This suggests that the addition of urea hindered DHH activity without affecting biomass size (microbial biomass $\mathrm{C}$ was comparable for the control and urea treatments). The decrease in DHH activity may have resulted from urea inhibiting certain metabolic processes or microbial groups rather than reducing the size of the entire microbial community. The findings of Omar and Ismail (1999) support this observation, but it was not confirmed by other researchers' results that reported no effects of urea on enzyme activities and microbial biomass size or only at rates much higher than those applied here (e.g. Banerjee et al., 1999). However, the studies investigating the effects of urea fertilisation on microbial soil properties were all field studies, i.e. environmental factors and plant growth might also have had an impact on the soil microbial community. Most results obtained under laboratory conditions cannot be used to predict microbial responses to amendments in situ (Madsen, 1996). For example, Thirukkumaran et al. (2002) reported a negative effect of $\mathrm{N}$ fertilisation on microbial biomass and respiration and litter decomposition that was not reproduced under field conditions. They concluded that the observed differences in microbial response between results from field and laboratory studies were due to the lack of plant and root growth activity and leaching in the laboratory experiment.

At day 3 and 6, microbial $\mathrm{N}$ levels were higher in the urea treatment compared to the control, indicating a larger microbial biomass or higher immobilisation activity after urea amendment. Similarly, Acquaye and Inubushi (2004) reported higher immobilisation rates and a larger increase in microbial $\mathrm{N}$ after fertilisation with urea compared with a slow-release fertiliser in the field. However, in their study microbial biomass size was more influenced by soil type than fertilisation. Immobilisation is known to be more pronounced when bacteria dominate in the soil (Vinten et al., 2002), which corresponds with a decline in microbial $\mathrm{C}: \mathrm{N}$ ratio directly after urea addition.

The application of the three treatments caused distinct differences in community structure of $\alpha$ proteobacterial, actinomycete and pseudomonad communities as assessed by PCR-DGGE analysis. Ten days after the amendment, microbial communities were most different in the control compared to the urea and lupin-amended soils, while these treatments were more similar to each other. At the end of the experiment, the trends were less clear and similarities among treatments had increased to a degree that grouping into distinct clusters proved impossible. These results indicate that addition or non-addition of $\mathrm{N}$ had an effect on the community composition of the microbial groups examined and that microbial communities in the soils changed due to the availability of additional substrate. The influence of fertiliser type was, however, less pronounced and differences in the community structure of lupin and urea amended soils were smaller than when compared to the control. The fertilisation effect was short-lived, as the communities were very similar after 91 days indicating that the stimulating influence of additional $\mathrm{N}$ was diminished.

\subsection{Linkages between microbial biomass size, activity and community structure}

As expected, positive, statistically significant correlations were observed among microbial biomass, activity, total $\mathrm{C}$ and $\mathrm{N}$ and gross $\mathrm{N}$ mineralisation rate. In contrast, mineral $\mathrm{N}$ content was 
negatively linked with the soil biological properties and $\mathrm{N}$ mineralisation reflecting the role microorganisms play in the N cycle (Smith, 1994; Puri and Ashman, 1998). It also indicates that immobilisation rates increase with microbial biomass and activity growth enhanced resulting in a decrease in total mineral N.

In the lupin treatment, a strong correlation of microbial biomass $\mathrm{C}$ to gross $\mathrm{N}$ mineralisation rate and DHH support the direct positive link between microbial growth and activity, while in the other treatments the correlations were not as pronounced. This supports the observation that adding lupin to the soils stimulated growth and activity of the microbial community simultaneously, while in the control and urea treatments changes in biomass size did not occur at the same time as changes in activity. This could indicate that the microbial community was more adapted to the urea amendment (increase in activity without growth response) (Barkle et al., 2001). The lack of correlation between $\mathrm{C}_{\mathrm{mic}}$ and gross mineralisation in the control and urea treatments could also suggest a limitation in decomposable compounds other than $\mathrm{N}$ in these treatments (most likely $\mathrm{C}$ ), resulting in nutrient supplies too low to sustain microbial cell synthesis and high activity levels. Similarly, Zaman et al. (1999) observed weak correlations of microbial biomass size and N mineralisation in incubated soils after the addition of ammonium chloride fertiliser.

The changes in microbial community composition following the amendments corresponded to those observed for microbial soil properties. Ten days after the addition of lupin and urea clear differences were visible in DGGE banding patterns of bacterial and actinomycete communities, and it was possible to distinguish amended from non-amended soils. By the end of the experiment, these differences had disappeared. In contrast, microbial C:N ratio was initially and overall more strongly affected by the urea amendment, while towards the end of the incubation period all soils were similar to each other.

Differences in the community structure were smaller between lupin and urea amended soils than between urea and control treatments. Microbial soil properties and total $\mathrm{C}$ and $\mathrm{N}$, on the other hand, were mainly influenced by the lupin addition and mineral $\mathrm{N}$ by the amendment with urea. Gross mineralisation rates were similar for all treatments. This indicates that no direct relationship exists between these soil properties and microbial community structure under the conditions used in this study. However, the differences in response to the amendments - i.e. one type of measurement was more influenced by the form of amendment (mineral or organic), while the other responded more strongly to the presence or absence of $\mathrm{N}$ - suggest that soil microbial properties, microbial function and community structure clearly measure different aspects of microbial diversity. The differences in the microbial activity or function might be reflected in changes in community structure of other organism groups (e.g. fungi) or of smaller subgroups of microorganisms or in the variation in species richness or dominant species.

\section{Conclusions}

Despite differences in farm management history, the microbial communities in both soils were sufficient to respond to the addition of organic matter and mineral N. Initially observed differences between soils in soil biological properties persisted over the incubation period. Similarly, the composition of the microbial assemblages assessed in this study was mainly influenced by management history, while treatment effects were not lasting. The presence or absence of $\mathrm{N}$ substrate had a strong effect on the community structure of bacteria and actinomycetes, while the influence of fertiliser type was less pronounced. Urea addition appeared to result in changes of other microbial components in the short-term.

Amendment with lupin stimulated the microbial communities resulting in an increase in microbial biomass size and activity, while the urea-amended soils were not significantly different from the control when analysed for soil biological properties.

Correlation analyses of microbial soil properties and processes for each treatment separately suggested differences in nutrient availability, microbial diversity and physiological properties 
among the treatments. No relationship between microbial community structure and activity or soil processes existed under the experimental conditions.

\section{Acknowledgements}

The authors acknowledge the technical assistance provided by Lincoln University Analytical Services. Many thanks to Hayley Ridgway, Emily Gerard, Tim Clough and Carole Barlow for practical help and advice. We also thank Andrew McLachlan for his statistical advice. Financial support for this study was provided by the New Zealand Fertiliser Manufacturers' Research Association and Lincoln University.

\section{References}

Acquaye, S., Inubushi, K., 2004. Comparative effects of application of coated and non-coated urea in clayey and sandy paddy soil microcosms examined by the ${ }^{15} \mathrm{~N}$ tracer technique. II. Effects on soil microbial biomass $\mathrm{N}$ and microbial ${ }^{15} \mathrm{~N}$ immobilization. Soil Sci. Plant Nutr. 50, 215-223.

Banerjee, M.R., Burton, D.L., Grant, C.A., 1999. Influence of urea fertilization and urease inhibitor on the size and activity of the soil microbial biomass under conventional and zero tillage at two sites. Canadian Journal of Soil Science 79, 255-263.

Bardgett, R.D., McAlister, E., 1999. The measurement of soil fungal:bacterial biomass ratios as an indicator of ecosystem self-regulation in temperate meadow grasslands. Biol. Fert. Soils 29, 282-290.

Barkle, G.F., Stenger, R., Sparling, G.P., Painter, D.J., 2001. Immobilisation and mineralisation of carbon and nitrogen from dairy farm effluent during laboratory soil incubations. Austr. J. Soil Res. 39, 1407-1417.

Barraclough, D., 1995. ${ }^{15} \mathrm{~N}$ isotope dilution techniques to study soil nitrogen transformations and plant uptake. Fert. Res. 42, 185-192.

Blakemore, L.C., Searle, P.L., Daly, B.K., 1987. Methods for chemical analysis of soils. NZ Soil Bur. Sci. Rep. 80, p. 103.

Bossio, D.A., Scow, K.M., Gunapala, N., Graham, K.J., 1998. Determinants of soil microbial communities: Effects of agricultural management, season, and soil type on phospholipid fatty acid profiles. Microbial Ecol. 36, 1-12.

Clegg, C.D., Lovell, R.D., Hobbs, P.J., 2003. The impact of grassland management regime on the community structure of selected bacterial groups in soils. FEMS Microbiol. Ecol. 43, $263-$ 270.

Di, H.J., Cameron, K.C., McLaren, R.G., 2000. Isotopic dilution methods to determine the gross transformation rates of nitrogen, phosphorus, and sulfur in soil: a review of the theory, methodologies, and limitations. Austr. J. Soil Res. 38, 213-230.

Doran, J.W., Fraser, D.G., Culik, M.N., Liebhardt, W.C., 1988. Influence of alternative and conventional agricultural management on soil microbial processes and nitrogen availability. Am. J. Alternative Agr. 2, 99-106.

Fauci, M.F., Dick, R.P., 1994. Soil microbial dynamics: short- and long-term effects of inorganic and organic nitrogen. Soil Sci. Soc. Am. J. 58, 801-806.

Fontaine, S., Mariotti, A., Abbadie, L., 2003. The priming effect of organic matter: a question of microbial competition? Soil Biol. Biochem. 35, 837-843.

Fraser, D.G., Doran, J.W., Sahs, W.W., Lesoing, G.W., 1988. Soil microbial populations and activities under conventional and organic management. J. Env. Qual. 17, 585-590.

Frey, S.D., Knorr, M., Parrent, J.L., Simpson, R.T., 2004. Chronic nitrogen enrichment affects the structure and function of the soil microbial community in temperate hardwood and pine forests. Forest Ecology and Management 196, 159-171. 
Girvan, M.S., Bullimore, J., Pretty, J.N., Osborn, A.M., Ball, A.S., 2003. Soil type is the primary determinant of the composition of the total and active bacterial communities in arable soils. Appl. Environ. Microbiol. 69, 1800-1809.

Gomes, N.C.M., Heuer, H., Schönfeld, J., Costa, R., Mendoça-Hagler, L., Smalla, K., 2001. Bacterial diversity of the rhizosphere of maize (Zea mays) grown in tropical soil studied by temperature gradient gel electrophoresis. Plant Soil 232, 167-180.

Gunapala, N., Scow, K.M., 1998. Dynamics of soil microbial biomass and activity in conventional and organic farming systems. Soil Biol. Biochem. 30, 805-816.

Heuer, H., Krsek, M., Baker, P., Smalla, K., Wellington, E.M.H., 1997. Analysis of actinomycete communities by specific amplification of genes encoding 16S rRNA and gel-electrophoretic separation in denaturing gradients. Appl. Environ. Microbiol. 63, 3233-3241.

Hole, D.G., Perkins, A.J., Wilson, J.D., Alexander, I.H., Grice, P.V., Evans, A.D., 2005. Does organic farming benefit biodiversity? Biol. Conserv. 122, 113-130.

Joergensen, R.G., Anderson, T.-H., Wolters, V., 1995. Carbon and nitrogen relationships in the microbial biomass of soils in beech Fagus sylvatica L. forests. Biology \& Fertility of Soils 19, 141-147.

Kirchmann, H., Thorvaldsson, G., 2000. Challenging targets for future agriculture. Eur. J. Agron. $12,145-161$.

Lovell, R.D., Jarvis, S.C., Bardgett, R.D., 1995. Soil microbial biomass and activity in long-term grassland: Effects of management changes. Soil Biol. Biochem. 27, 969-975.

Lundquist, E.J., Scow, K.M., Jackson, L.E., Uesugi, S.L., Johnson, C.R., 1999. Rapid response of soil microbial communities from conventional, low input, and organic farming systems to a wet/ dry cycle. Soil Biol. Biochem. 31, 1661-1675.

Madsen, E.L., 1996. A critical analysis of methods for determining the composition and biogeochemical activities of soil microbial communities in situ. In: Bollag, J.-M., Stotzky, G. (Eds.), Soil biochemistry, Marcel Dekker, New York, USA, Vol. 9, pp. 287-370.

Mahmood, T., Azam, F., Hussain, F., Malik, K.A., 1997. Carbon availability and microbial biomass in soil under an irrigated wheat-maize cropping system receiving different fertilizer treatments. Biol. Fert. Soils 25, 63-68.

Marschner, P., Kandeler, E., Marschner, B., 2003. Structure and function of the soil microbial community in a long-term fertilizer experiment. Soil Biol. Biochem. 35, 453-461.

Muyzer, G., de Waal, E., Uitterlinden, A., 1993. Profiling of complex microbial populations by denaturing gradient gel electrophoresis analysis of polymerase chain reaction-amplified genes coding for 16S rRNA. Appl. Environ. Microbiol. 59, 695-700.

Ohtonen, R., Fritze, H., Pennanen, T., Jumpponen, A., Trappe, J., 1999. Ecosystem properties and microbial community changes in primary succession on a glacier forefront. Oecologia 119, 239-246.

Omar, S.A., Ismail, M.A., 1999. Microbial populations, ammonification and nitrification in soil treated with urea and inorganic salts. Folia Microbiol. (Prague) 44, 205-212.

Puri, G., Ashman, M.R., 1998. Relationship between soil microbial biomass and gross N mineralisation. Soil Biol. Biochem. 30, 251-256.

Robertson, F.A., Morgan, W.C., 1996. Effects of management history and legume green manure on soil microorganisms under 'organic' vegetable production. Austr. J. Soil Res. 34, 427-440.

Sanguinetty, C.J., Dias Neto, E., Simpson, A.J.G., 1994. Rapid silver staining and recovery of PCR products on acrylamide gels. Biotechniques 17, 915-919.

Shepherd, M., Harrison, R., Cuttle, S., Johnson, B., Shannon, D., Gosling, P., Rayns, F., 2000. Understanding of soil fertility in organically farmed soils. Produced for UK Ministry of Agriculture, Fisheries and Food. Retrieved April 2000 from http://www.adas.co.uk/soilfertility/download.html?topid=7 (last accessed 26/04/2005).

Smith, J.L., 1994. Cycling of nitrogen through microbial activity. In: Hatfield, J.L., Stewart, B.A. (Eds.), Soil Biology: Effects on Soil Quality, Lewis Publishers, Boca Raton, USA, pp. 91120. 
Smith, R.S., Shiel, R.S., Bardgett, R.D., Millward, D., Corkhill, P., Rolph, G., Hobbs, P.J., Peacock, S., 2003. Soil microbial community, fertility, vegetation and diversity as targets in the restoration management of a meadow grassland. Journal of Applied Ecology 40, 51-64.

Sparling, G.P., West, A.W., 1988. Modifications to the fumigation extraction technique to permit simultaneous extraction and estimation of soil microbial C and N. Commun. Soil Sci. Plant Anal. 19, 327-344.

Stark, J.M., Hart, S.C., 1996. Diffusion technique for preparing salt solutions, Kjeldahl digests, and persulfate digests for nitrogen-15 analysis. Soil Sci. Soc. Am. J. 60, 1846-1855.

Stolze, M., Piorr, A., Häring, A., Dabbert, S., 2000. Environmental impacts of organic farming in Europe. University of Hohenheim, Stuttgart, Germany, Organic farming in Europe: Economics and policy Vol. 6.

Thalmann, A., 1968. Zur Methodik der Bestimmung der Dehydrogenaseaktivität im Boden mittels Triphenyltetrazoliumchlorid (TTC). Landw. Forsch. 21, 249-250.

Thirukkumaran, C.M., Parkinson, D., 2002. Microbial activity, nutrient dynamics and litter decomposition in a Canadian Rocky Mountain pine forest as affected by $\mathrm{N}$ and $\mathrm{P}$ fertilizers. Forest Ecol. Manage. 159, 187-201.

Vinten, A.J.A., Whitmore, A.P., Bloem, J., Howard, R., Wright, F., 2002. Factors affecting N immobilisation/mineralisation kinetics for cellulose-, glucose- and straw-amended sandy soils. Biol. Fert. Soils 36, 190-199.

Wander, M.M., Traina, S.J., Stinner, B.R., Peters, S.E., 1994. Organic and conventional management effects on biologically active soil organic matter pools. Soil Sci. Soc. Am. J. $58,1130-1139$.

Ward, J.H., 1963. Hierarchical grouping to optimize an objective function. J. Am. Statist. Assn. 58, 236-244.

Watson, C.A., Atkinson, D., Gosling, P., Jackson, L.R., Rayns, F.W., 2002. Managing soil fertility in organic farming systems. Soil Use Manage. 18, 239-247.

Weisburg, W.G., Barns, S.M., Pelletier, D.A., Lane, D.J., 1991. 16S ribosomal DNA amplification for phylogenetic study. J. Bacteriol. 173, 697-703.

Widmer, F., Seidler, R.J., Gillevet, P.M., Watrud, L.S., di Giovanni, G.D., 1998. A highly selective PCR protocol for detecting 16S rRNA genes of the genus Pseudomonas (sensu stricto) in environmental samples. Appl. Environ. Microbiol. 64, 2545-2553.

Zaman, M., Di, H.J., Cameron, K.C., Frampton, C.M., 1999. Gross nitrogen mineralization and nitrification rates and their relationships to enzyme activities and the soil microbial biomass in soils treated with dairy shed effluent and ammonium fertilizer at different water potentials. Biol. Fert. Soils 29, 178-186. 
Table 1.

Chemical and physical soil properties of ORG and CON topsoil samples $(0-15 \mathrm{~cm})$.

\begin{tabular}{lll}
\hline Soil property & ORG & CON \\
\hline $\mathrm{C}\left(\mu \mathrm{g} \mathrm{g}^{-1}\right)$ & 0.27 & 0.29 \\
$\mathrm{~N}\left(\mu \mathrm{g} \mathrm{g}^{-1}\right)$ & 0.0024 & 0.0024 \\
$\mathrm{C}: \mathrm{N} \mathrm{ratio}$ & 11.4 & 12.1 \\
$\mathrm{~S}\left(\mu \mathrm{g} \mathrm{g}^{-1}\right)$ & 260 & 300 \\
$\mathrm{pH}$ & 6.1 & 5.7 \\
$\mathrm{Soil} \mathrm{resin} \mathrm{P}\left(\mu \mathrm{g} \mathrm{g}^{-1}\right)$ & 45 & 37 \\
Total P $\left(\mu \mathrm{g} \mathrm{g}^{-1}\right)$ & 813 & 771 \\
$\mathrm{CEC}\left(\mathrm{cmol}_{\mathrm{c}} \mathrm{kg}^{-1}\right)$ & 14 & 14 \\
$\mathrm{Ca}\left(\mathrm{cmol}_{\mathrm{c}} \mathrm{kg}^{-1}\right)$ & 7.3 & 7.0 \\
$\mathrm{Mg}\left(\mathrm{cmol}_{\mathrm{c}} \mathrm{kg}^{-1}\right)$ & 0.79 & 0.56 \\
$\mathrm{~K}\left(\mathrm{cmol}_{\mathrm{c}} \mathrm{kg}^{-1}\right)$ & 0.76 & 0.39 \\
$\mathrm{Na}\left(\mathrm{cmol}_{\mathrm{c}} \mathrm{kg}^{-1}\right)$ & 0.17 & 0.19 \\
Water holding capacity $(\%)(\mathrm{w}: \mathrm{w})$ & 27.2 & 31.6 \\
Bulk density $\left(\mathrm{g} \mathrm{cm}^{-3}\right)$ & 1.44 & 1.38 \\
\hline
\end{tabular}


Table 2.

Effects of the factors soil origin (farm), treatment, time and their interactions influencing the following soil properties and processes determined over

91 days of incubation by repeated measures analysis: microbial biomass $\mathrm{C}$ and $\mathrm{N}\left(\mathrm{C}_{\text {mic }}, \mathrm{N}_{\text {mic }}\right)$, microbial C:N ratio, dehydrogenase activity (DHH), total mineral $\mathrm{N}\left(\mathrm{N}_{\min }\right)$, gross $\mathrm{N}$ mineralisation $(\mathrm{MIN})$, total $\mathrm{C}$ and $\mathrm{N}\left(\mathrm{C}_{\text {tot }}, \mathrm{N}_{\text {tot }}\right)$, total C:N ratio and microbial quotient $\left(\mathrm{C}_{\text {mic }}: \mathrm{C}_{\text {tot }}\right)$.

\begin{tabular}{|c|c|c|c|c|c|c|c|c|c|c|c|c|c|c|}
\hline & \multicolumn{2}{|c|}{ Farm } & \multicolumn{2}{|c|}{ Treatment } & \multicolumn{2}{|c|}{ Farm x Treatment } & \multicolumn{2}{|c|}{ Time } & \multicolumn{2}{|c|}{ Time x Farm } & \multicolumn{2}{|c|}{$\begin{array}{c}\text { Time } x \\
\text { Treatment }\end{array}$} & \multicolumn{2}{|c|}{$\begin{array}{c}\text { Time } \mathrm{x} \text { Farm } \mathrm{x} \\
\text { Treatment } \\
\end{array}$} \\
\hline & F value & $\mathrm{p}$ value & F value & $\mathrm{p}$ value & F value & $p$ value & F value & $\mathrm{p}$ value & F value & $\mathrm{p}$ value & F value & $\mathrm{p}$ value & F value & $\mathrm{p}$ value \\
\hline $\mathrm{C}_{\text {mic }}$ & 0.24 & 0.636 & 900 & $<0.001$ & 2.61 & 0.115 & 78.5 & $<0.001$ & 4.2 & 0.008 & 20.8 & $<0.001$ & 1.17 & 0.343 \\
\hline $\mathrm{N}_{\text {mic }}$ & 7.75 & 0.02 & 246 & $<0.001$ & 5.32 & 0.02 & 32.4 & $<0.001$ & 4.56 & 0.009 & 3.28 & 0.01 & 0.83 & 0.55 \\
\hline microbial C:N & 1.62 & 0.23 & 2.88 & 0.095 & 0.58 & 0.58 & 3.86 & 0.03 & 4.79 & 0.02 & 3.26 & 0.03 & 2.32 & 0.085 \\
\hline $\mathrm{DHH}$ & 289 & $<0.001$ & 1182 & $<0.001$ & 44.4 & $<0.001$ & 162 & $<0.001$ & 14.3 & $<0.001$ & 48.7 & $<0.001$ & 2.49 & 0.04 \\
\hline $\mathrm{N}_{\min }$ & 89.1 & $<0.001$ & 344 & $<0.001$ & 0.57 & 0.58 & 34.5 & $<0.001$ & 1.24 & 0.3 & 3.79 & 0.04 & 1.0 & 0.41 \\
\hline MIN & 13.3 & 3.85 & 0.89 & 0.25 & 1.92 & 0.001 & 9.64 & 0.03 & 0.96 & 0.04 & 4.13 & 0.05 & 3.81 & 0.01 \\
\hline $\mathrm{C}_{\text {tot }}$ & 835 & $<0.001$ & 27.3 & $<0.001$ & 0.06 & 0.95 & 1.1 & 0.36 & 1.41 & 0.26 & 0.97 & 0.46 & 0.27 & 0.93 \\
\hline $\mathrm{N}_{\text {tot }}$ & 527 & $<0.001$ & 37.2 & $<0.001$ & 0.33 & 0.72 & 6.14 & 0.002 & 3.06 & 0.05 & 0.71 & 0.63 & 0.55 & 0.76 \\
\hline $\mathrm{C}: \mathrm{N}$ ratio & 0.48 & 0.006 & 4.82 & $<0.001$ & 0.04 & 0.647 & 3.21 & $<0.001$ & 0.90 & 0.055 & 0.48 & 0.52 & 0.42 & 0.576 \\
\hline $\mathrm{C}_{\text {mic }}: \mathrm{C}_{\text {tot }}$ & 73 & $<0.001$ & 634 & $<0.001$ & 9.48 & 0.003 & 0.002 & $<0.001$ & 5.32 & 0.001 & 20.3 & $<0.001$ & 1.51 & 0.18 \\
\hline
\end{tabular}


Table 3.

Overall mean values (standard error of means) of selected soil properties determined for the treatments (control, lupin, urea) and the two farms (ORG and CON) over 91 days of incubation. Abbreviations as outlined for Table 1.

\begin{tabular}{|c|c|c|c|c|c|c|c|c|c|}
\hline & $\begin{array}{l}\mathrm{C}_{\mathrm{mic}} \\
\left.(\mu \mathrm{g} \mathrm{C} \mathrm{g})^{-1}\right)\end{array}$ & $\begin{array}{l}\mathrm{N}_{\text {mic }} \\
\left(\mu \mathrm{g} \mathrm{N} \mathrm{g}{ }^{-1}\right)\end{array}$ & microbial C:N & $\begin{array}{l}\text { DHH } \\
\left(\mu \mathrm{g} \text { TPF } g^{-1} h^{-1}\right)\end{array}$ & $\begin{array}{l}\mathrm{N}_{\min } \\
\left(\mu \mathrm{g} \mathrm{g}^{-1}\right)\end{array}$ & $\begin{array}{l}\mathrm{C} \\
(\%)\end{array}$ & $\begin{array}{l}\mathrm{N} \\
(\%)\end{array}$ & $\mathrm{C}: \mathrm{N}$ ratio & $\begin{array}{l}\mathrm{C}_{\text {mic }}: \mathrm{C}_{\text {tot }} \\
(\%)\end{array}$ \\
\hline \multicolumn{10}{|l|}{ Treatment } \\
\hline Control & $362.2(8.00)$ & $34.5(1.02)$ & $10.8(0.33)$ & $1.56(0.07)$ & $78.6(2.82)$ & $2.51(0.03)$ & $0.207(0.003)$ & $12.1(0.04)$ & $1.45(0.04)$ \\
\hline Lupin & $670.2(25.4)$ & $62.3(2.21)$ & $10.8(0.21)$ & $4.28(0.27)$ & $85.7(3.63)$ & $2.60(0.03)$ & $0.220(0.003)$ & $11.8(0.07)$ & $2.59(0.11)$ \\
\hline Urea & $343.9(9.54)$ & $37.3(1.56)$ & $9.73(0.42)$ & $1.36(0.09)$ & $164.0(8.21)$ & $2.50(0.03)$ & $0.215(0.003)$ & $11.6(0.05)$ & $1.38(0.04)$ \\
\hline $\mathrm{LSD}_{0.05}$ & 19.9 & 3.17 & 1.27 & 0.15 & 7.33 & 0.034 & 0.004 & 0.10 & 0.09 \\
\hline \multicolumn{10}{|l|}{ Farm } \\
\hline ORG & $459.7(25.0)$ & $46.3(2.38)$ & $10.12(0.25)$ & $2.88(0.26)$ & $91.4(6.38)$ & $2.35(0.01)$ & $0.199(0.001)$ & $11.8(0.05)$ & $1.95(0.10)$ \\
\hline $\mathrm{CON}$ & $457.8(22.9)$ & $43.0(1.87)$ & $10.78(0.29)$ & $1.91(0.18)$ & $127.5(6.49)$ & $2.73(0.01)$ & $0.229(0.002)$ & $11.9(0.05)$ & $1.67(0.08)$ \\
\hline Significance & NS & $*$ & NS & $* * *$ & $* * *$ & $* * *$ & $* * *$ & $* * *$ & $* * *$ \\
\hline
\end{tabular}

$\mathrm{n}=42$ for treatment means and $\mathrm{n}=63$ for site means. 
Table 4.

Correlation coefficients determined among soil properties and processes for the control, lupin and urea treatments over 91 days of incubation. Abbreviations as outlined for Table 1.

\begin{tabular}{|c|c|c|c|c|c|c|}
\hline & $\mathrm{C}_{\text {mic }}$ & $\mathrm{N}_{\text {mic }}$ & $\mathrm{DHH}$ & $\mathrm{N}_{\min }$ & $\mathrm{C}_{\text {tot }}$ & $\mathrm{N}_{\text {tot }}$ \\
\hline \multicolumn{7}{|c|}{ Control } \\
\hline $\mathrm{N}_{\text {mic }}$ & $0.45^{* *}$ & & & & & \\
\hline DHH & 0.23 & 0.13 & & & & \\
\hline $\mathrm{N}_{\min }$ & $-0.41^{*}$ & $-0.33^{*}$ & $-0.53 * *$ & & & \\
\hline $\mathrm{C}_{\text {tot }}$ & -0.05 & -0.004 & $-0.54 * *$ & $0.80 * * *$ & & \\
\hline $\mathrm{N}_{\text {tot }}$ & 0.07 & 0.002 & $-0.47 * *$ & $0.73 * * *$ & $0.97 * * *$ & \\
\hline MIN & -0.03 & -0.04 & 0.20 & $-0.45^{* *}$ & $-0.43^{*}$ & $-0.44 * *$ \\
\hline \multicolumn{7}{|l|}{ Lupin } \\
\hline $\mathrm{N}_{\text {mic }}$ & $0.88 * * *$ & & & & & \\
\hline DHH & $0.76^{* * *}$ & $0.87 * * *$ & & & & \\
\hline $\mathrm{N}_{\min }$ & $-0.63 * * *$ & $-0.74 * * *$ & $-0.76 * * *$ & & & \\
\hline $\mathrm{C}_{\text {tot }}$ & -0.02 & $-0.32^{*}$ & $-0.52 * *$ & $0.57 * *$ & & \\
\hline $\mathrm{N}_{\text {tot }}$ & 0.11 & -0.18 & $-0.37^{*}$ & $0.46^{* *}$ & $0.90 * * *$ & \\
\hline MIN & $0.50 * *$ & $0.32 *$ & $0.37^{*}$ & $-0.64 * * *$ & -0.08 & -0.18 \\
\hline \multicolumn{7}{|l|}{ Urea } \\
\hline $\mathrm{N}_{\text {mic }}$ & $0.49 * *$ & & & & & \\
\hline DHH & 0.11 & $0.54 * *$ & & & & \\
\hline $\mathrm{N}_{\min }$ & -0.04 & -0.18 & $-0.60 * *$ & & & \\
\hline $\mathrm{C}_{\text {tot }}$ & 0.22 & 0.04 & $-0.54 * *$ & $0.48^{* *}$ & & \\
\hline $\mathrm{N}_{\text {tot }}$ & $0.31 *$ & 0.10 & $-0.48 * *$ & $0.46^{* *}$ & $0.97 * * *$ & \\
\hline MIN & 0.09 & 0.07 & $0.60 * *$ & $-0.64 * * *$ & $-0.82 * * *$ & $-0.72 * * *$ \\
\hline
\end{tabular}



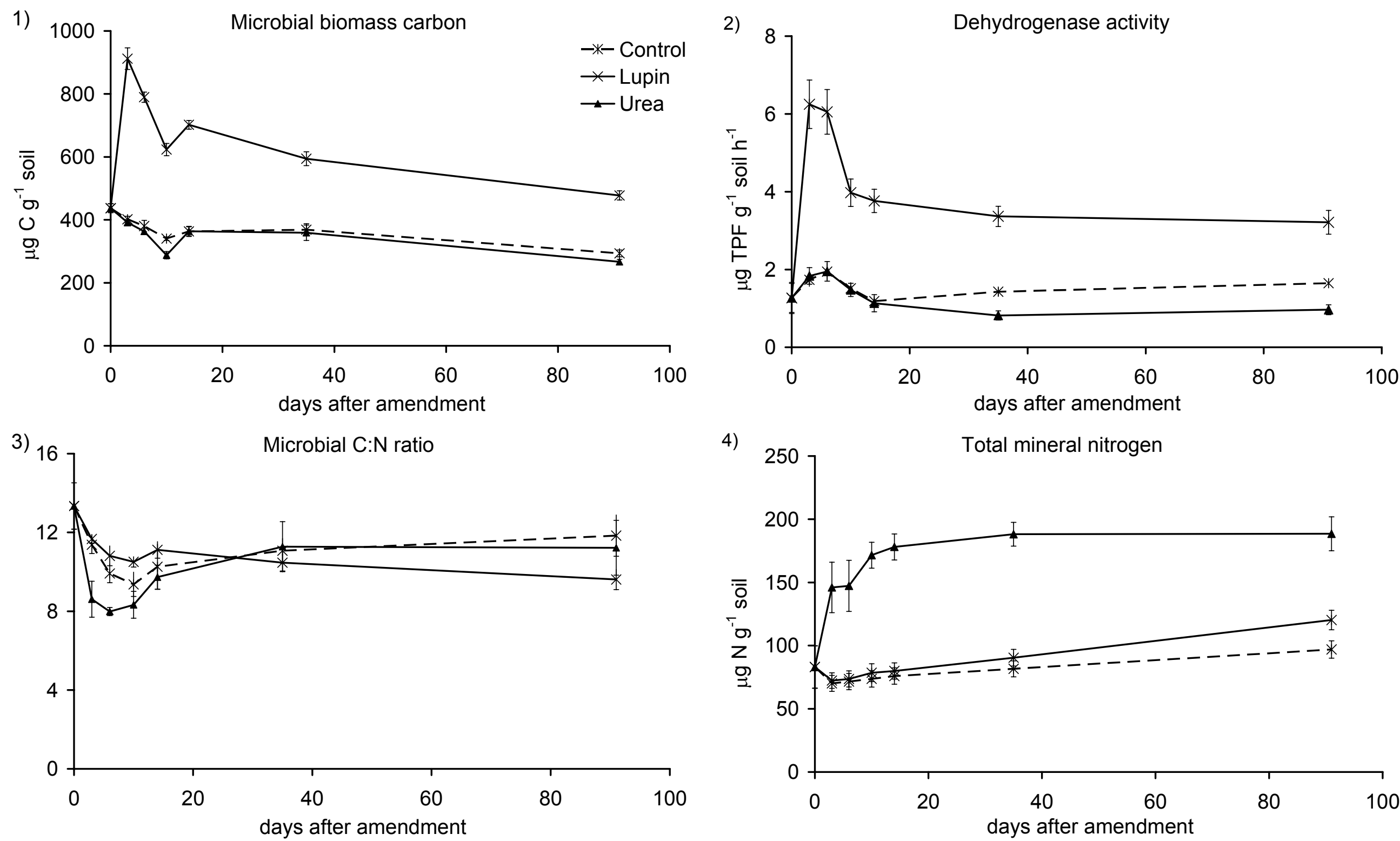

Fig 1. Changes in mean levels of microbial biomass C (1), dehydrogenase activity (2), microbial C:N ratio (3) and total mineral $\mathrm{N}(4)$ for three treatments over time. Values are means of two soils. Bars show standard errors of means. $n=18$. 

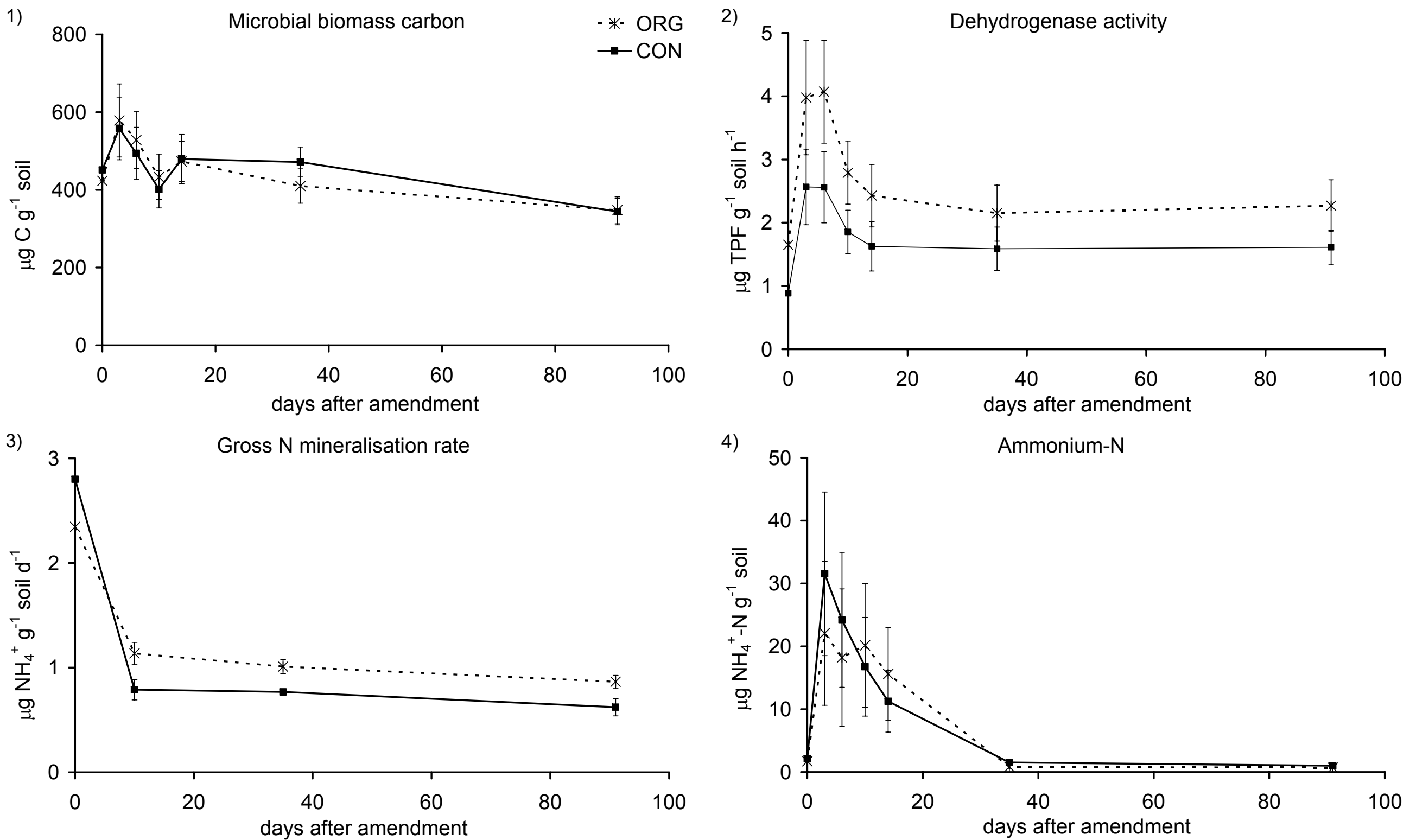

Fig. 2. Changes in mean microbial biomass $\mathrm{C}(1)$, dehydrogenase activity (2), gross $\mathrm{N}$ mineralisation rate and $\mathrm{NH}_{4}-\mathrm{N}_{\text {levels }}$ (4) for ORG and CON over 91 days of incubation. Bars show standard errors of means. $n=27$. 
1) 10 days

ORG

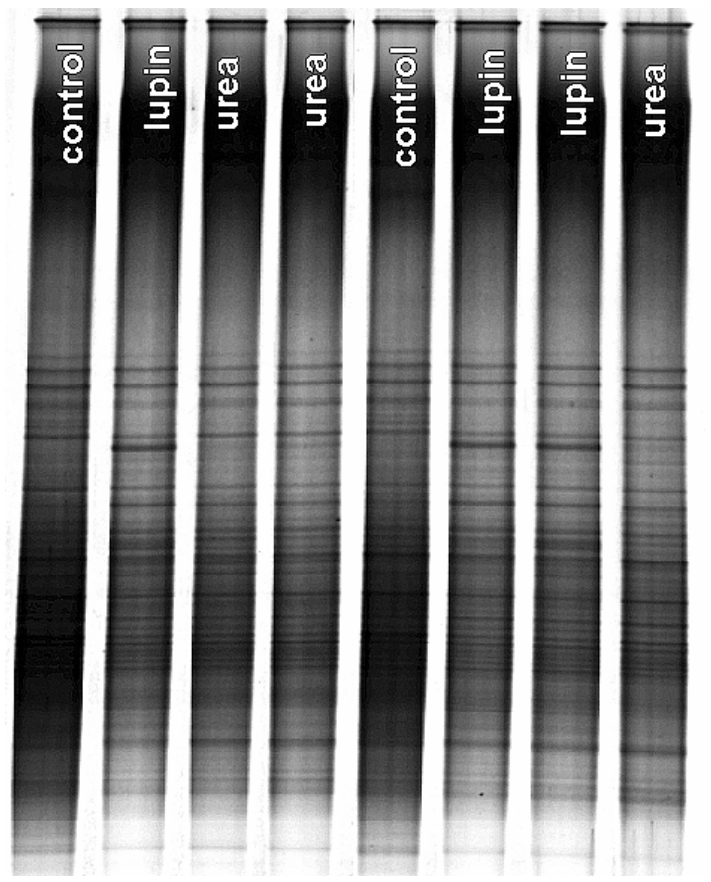

2) 91 days

ORG

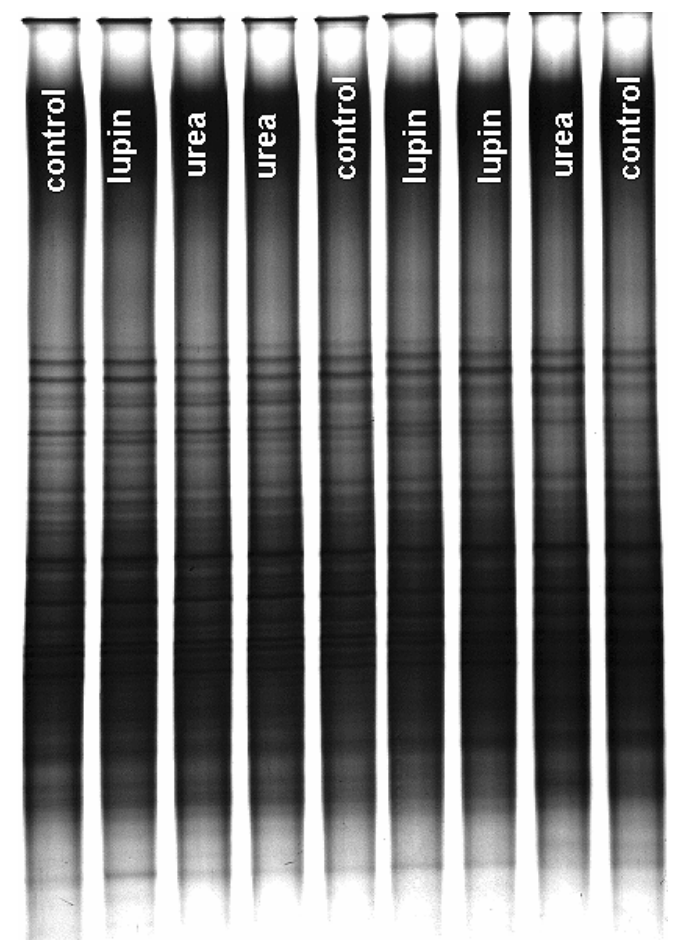

CON

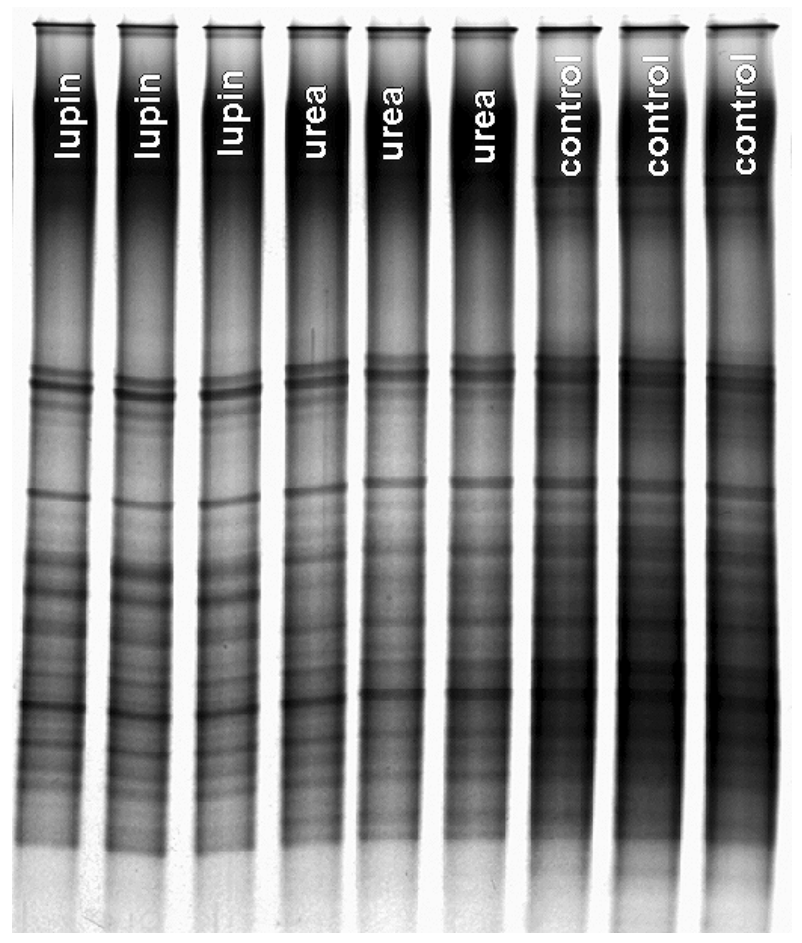

CON

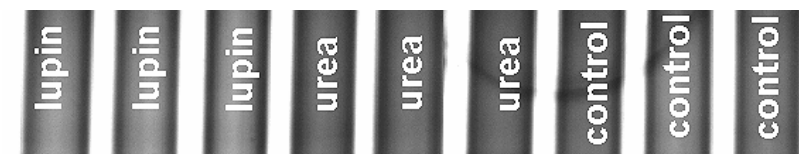

Fig. 3. DGGE profiles for actinomycete communities in ORG and CON soils sampled after 10 (1) and 91 (2) days of incubation. 


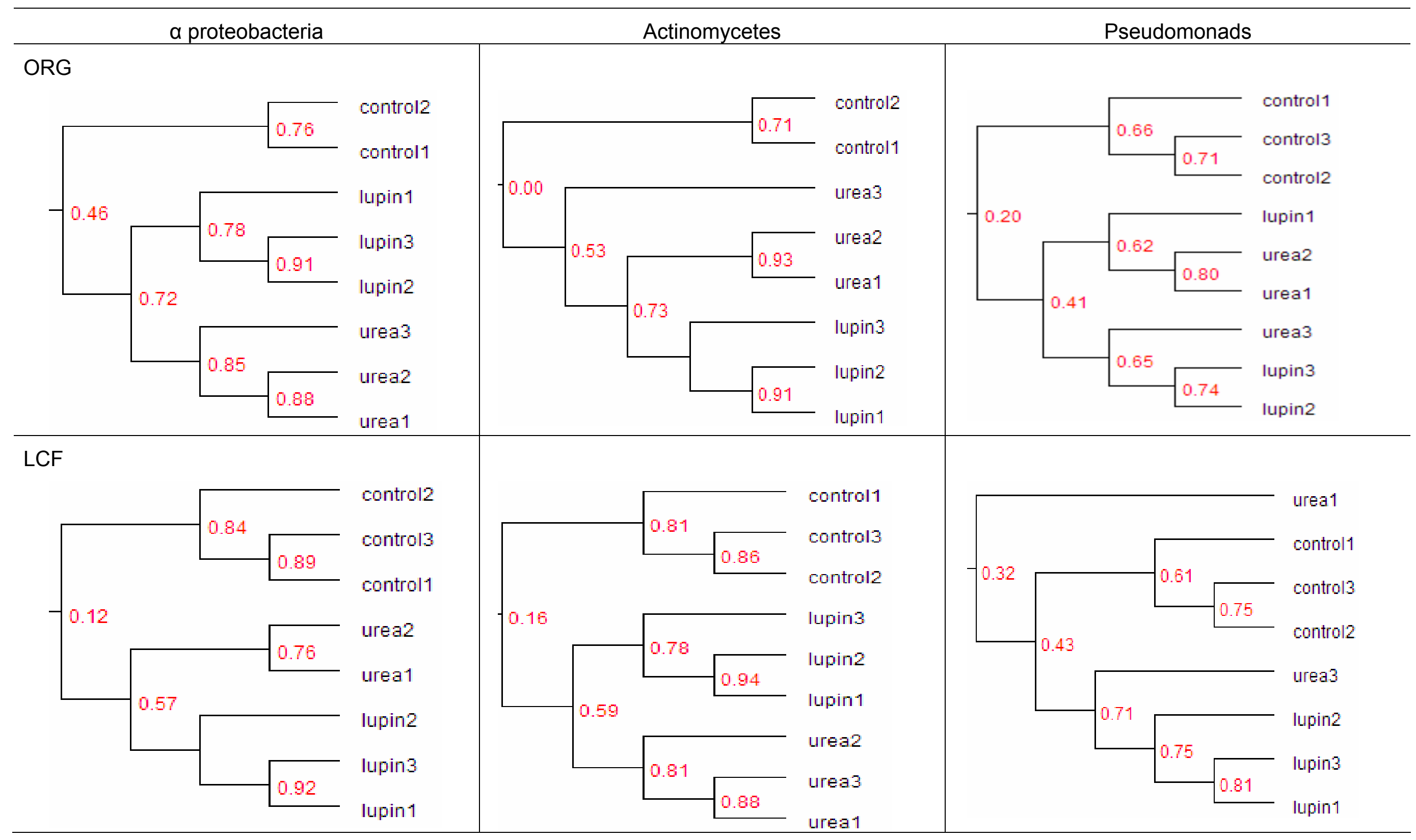

Fig. 4. Results of cluster analysis for different bacterial communities in ORG and CON soils after 10 days of incubation. 


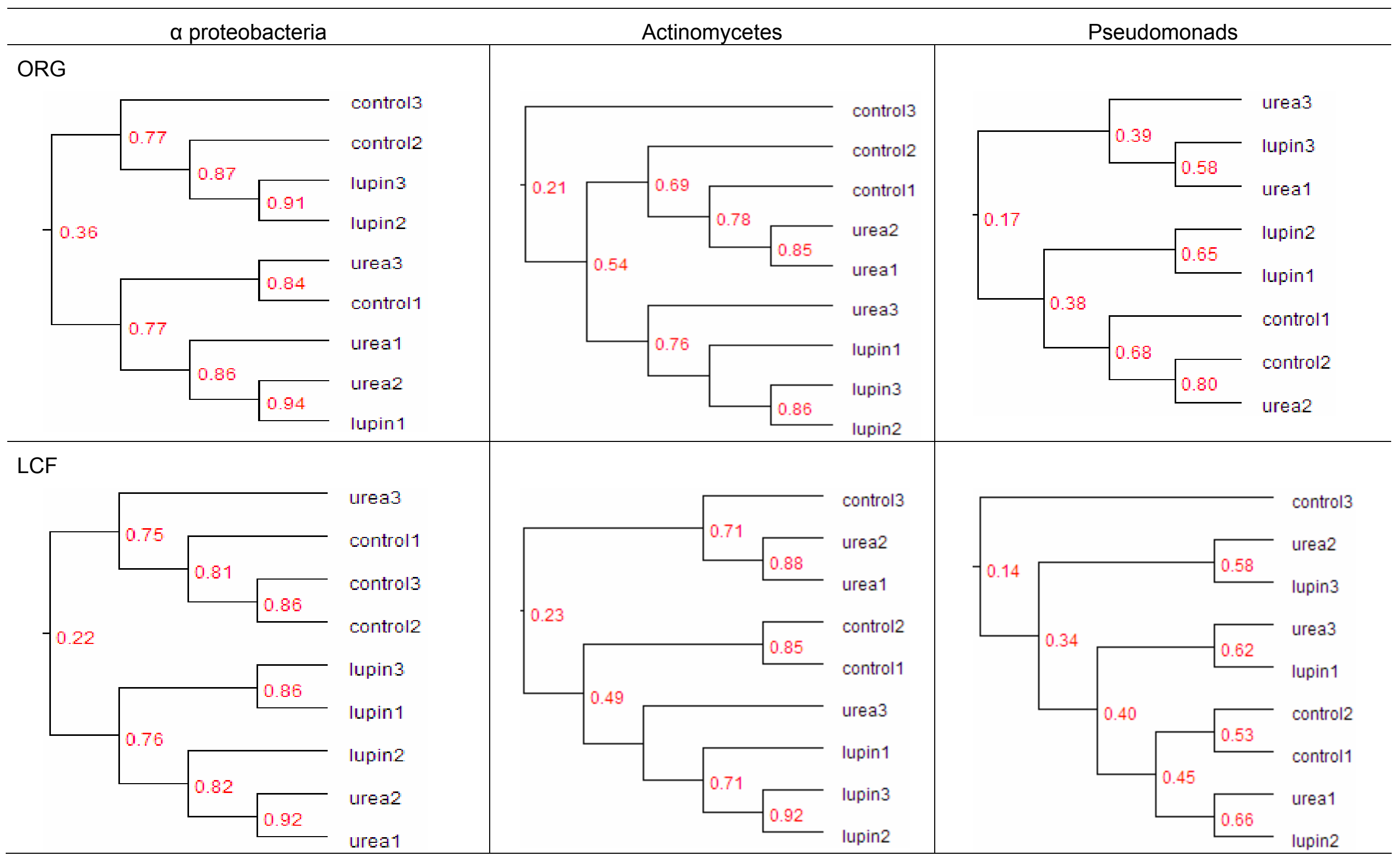

Fig. 5. Results of cluster analysis for different bacterial communities in ORG and CON soils after 91 days of incubation. 